\title{
A case of metastatic malignant melanoma presenting with large axillary mass and massive ascites mimicking hematologic malignancy
}

\author{
Hematolojik malignite büyük aksiller kitle ve masif assit ile taklit eden \\ metastatik malign melanom olgusu
}

\author{
Bahar Engin, ${ }^{1}$ Bengü Erkul, ${ }^{1}$ Alp Özgüzer, ${ }^{2}$ Muhammed Ali Kaypak, ${ }^{1}$ Mustafa Değirmenci, ${ }^{3}$ Harun Akar ${ }^{1}$ \\ ${ }^{1}$ Department of Internal Medicine, Tepecik Training and Research Hospital, İzmir, Turkey \\ ${ }^{2}$ Department of Pathology, Tepecik Training and Research Hospital, İzmir, Turkey \\ ${ }^{3}$ Department of Medical Oncology Outpatient Unit, Tepecik Training and Research Hospital, İzmir, Turkey
}

\begin{abstract}
Malignant melanoma is not only a type of skin cancer but also characterized with a wide spectrum of clinical signs and symptoms. In this article we report a 32-year-old male case who was admitted to internal medicine clinic for his large axillary mass and massive ascites that was initially thought to be due to hematologic malignancy. During our clinical follow-up an ulcerated skin lesion was noticed. Both the pathological evaluations of axillary mass and skin lesion revealed metastatic malignant melanoma.

Keywords: Ascites; axillary mass; biopsy; malignant melanoma; skin lesions.
\end{abstract}

ÖZ

Malign melanom yalnızca bir deri kanseri türü değil, aynı zamanda geniş bir klinik belirti ve bulgular yelpazesinde tanımlanmaktadır. Bu yazıda, büyük aksiller kitle ve masif assit nedeniyle dahiliye kliniğine başvuran ve başlangıçta hematolojik malignite olduğu düşünülen 32 yaşında bir erkek olgu sunuldu. Klinik takip sırasında ülserli deri lezyonu dikkati çekti. Hem aksiller kitle hem de cilt lezyonunun patolojik değerlendirmesinde metastatik malign melanom ortaya konuldu.

Anahtar sözcükler: Assit; aksiller kitle; biopsy; malign melanoma; deri lezyonları.

Malignant melanoma has a variety of morphologic faces and can metastasize and mimic any type of neoplastic process creating significant diagnostic challenges. ${ }^{[1-3]}$ Melanoma is one of the most rapidly progressive skin cancers and has a tendency to metastasize to many different organs. ${ }^{[2]}$ A young man was admitted to internal medicine clinic for his large axillary mass and massive ascites that was initially thought to be due to hematologic malignancy but later refuted by pathological and immunohistochemical examination of the biopsies from erroneous diagnostic considerations as hematologic malignancy.

\section{CASE REPORT}

A 32-year-old man with a large axillary mass and massive ascites was referred to the hematology outpatient unit with concerns regarding hematologic malignancy. The patient was subsequently transferred and admitted to the internal medicine clinic in our hospital. The patient stated that axillary mass had been present for the preceding 12 months. The initial presentation of this patient would suggest a case of axillary lymphadenopathy. He worked in a furniture factory that possibly contained chemical material in the environment. On the 
physical examination, he was pale and fair. He had no fever. His vital functions were normal. $\mathrm{He}$ had abdominal distension and Ballotmann's sign revealing ascites. The left axillary mass was firm, fixed, and painless. General surgery was consulted, and the patient subsequently underwent a biopsy of his large axillary mass by a tru-cut needle. He described a history of another mass in the past that were believed to be benign by his surgeon. Laboratory studies revealed mild hypoalbuminemia $(2.5 \mathrm{mg} / \mathrm{dL})$. Hemogram, kidney and liver function tests were normal. In his neck thorax abdomen $\mathrm{CT}$, there were multiple mediastinal, subcarinal, supraclavicular lymphadenopathies and an $11 \mathrm{~cm}$ in diameter axillary mass. In PET-CT, there was an $11 \mathrm{~cm}$ in diameter mass filling the left axilla and enlarged to the interpectoral area. There were also multiple liver and lytic bone metastases (Figure 1a). A written informed consent was obtained from the patient.

The patient underwent paracentesis. The following results were obtained on routine analysis: Serum-ascites albumin gradient was below 1.1 with high protein concentration. The ascites cytology was non-diagnostic. During our follow-up visit, we noticed a $2.5 \times 1.5 \mathrm{~cm}$ diameter ulcerated lesion on the left side of his temporal area next to hairy scalp. The skin lesion was excised by a plastic surgeon. The tru-cut biopsies of the axillary mass were reported as metastasis of nodular malignant melanoma. MelanA, HMB45, Vimentin, S100, WT-1, P53 stainings were all positive and Ki 67 proliferation index was 75\%. Pansitokeratin, nestin, synaptophysin, chromogranin dyes were negative (Figure 2). The excisional biopsy of the skin lesion was reported as nodular malignant melanoma. Breslow invasion thickness was $7 \mathrm{~mm}$, Clark level was 5, with vertical and lymphovascular invasion. Mitotic activity was 15 pcs in 10x. The patient was transferred to an oncology clinic for specific treatment. He was given B-RAF inhibitor, dabrafenib and MEK inhibitor trametinib for three months. At the end of three months of treatment, his lesion had shrinked and his laboratory findings were partially improved (Figure 1b).

\section{DISCUSSION}

Identification of specific tumor types may allow curative therapy to be instituted. Two tasks are expected before a diagnosis of malignancy must be established and a primary site must be sought. These will permit classification, prognostication and direct therapeutic intervention. Patients with cancers with an unknown primary site may present with widespread metastatic disease, pleural effusion or malignant ascites and may exhibit constitutional symptoms and signs such as weight loss, cachexia and fatigue. Initial presentation sites include liver, lungs, lymph nodes and bones.
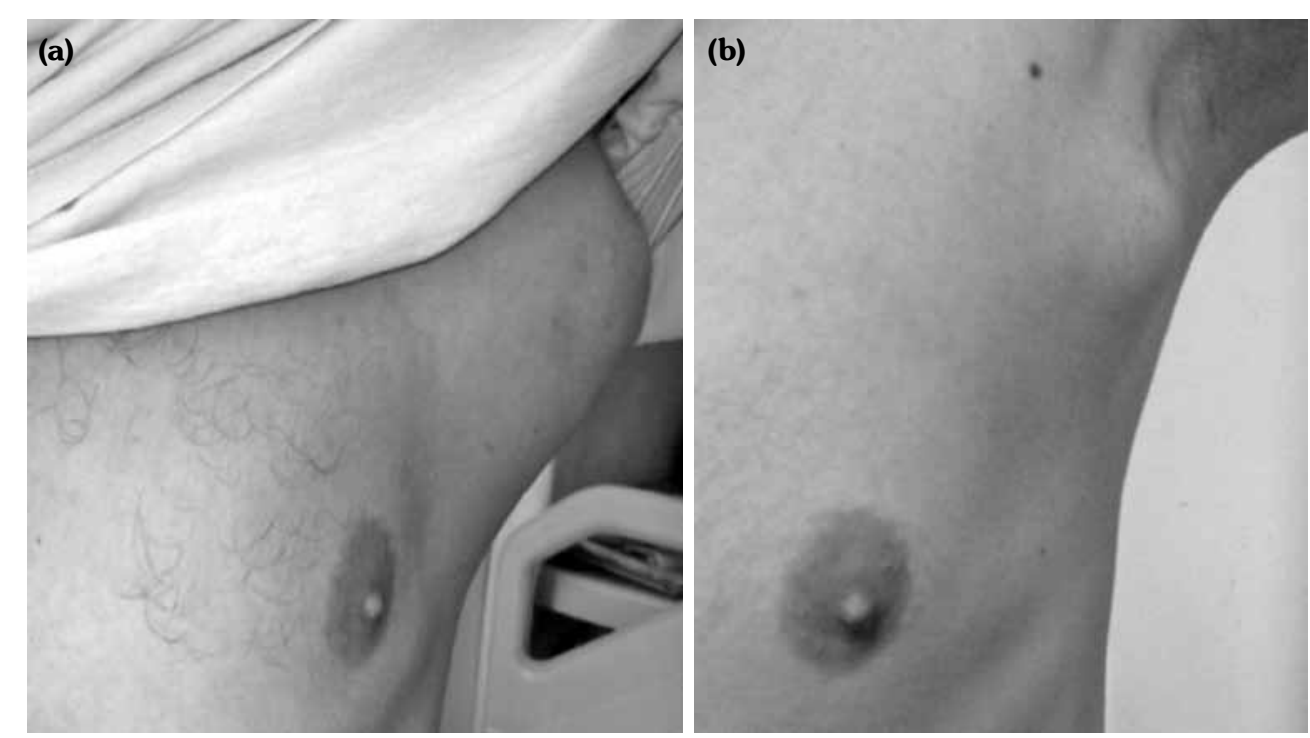

Figure 1. (a) The initial presentation of the axillary mass. It was firm, fixed, painless, with no pigmentation or ulceration. (b) The mass was seen after treatment with B-RAF inhibitor and MEK inhibitor. 

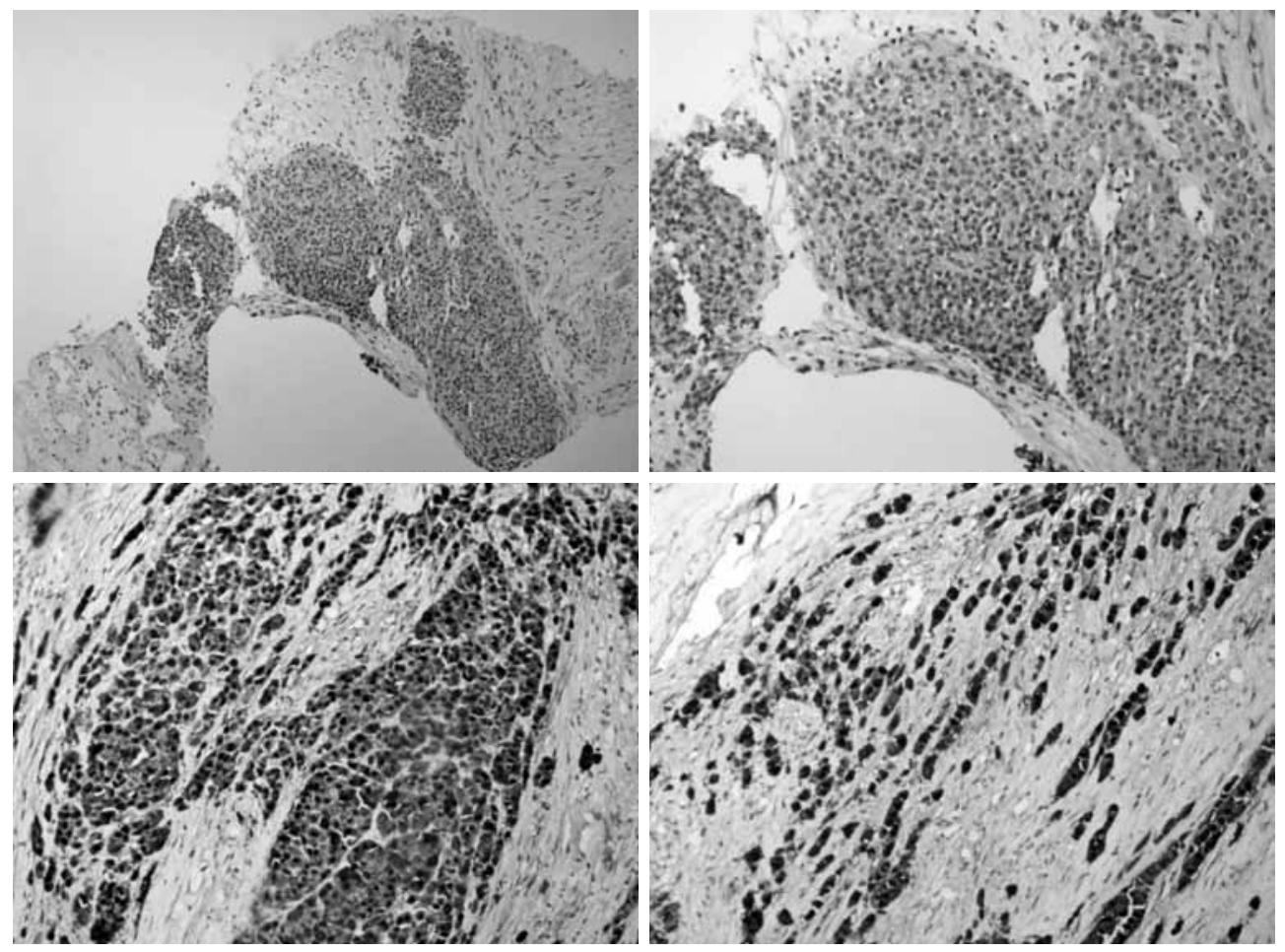

Figure 2. Histopathological images of axillary mass on the top, Hematoxilen Eozin dying and on the bottom, left side S100, right side HMB45 dying.

Workups should always begin with a precise history and a physical examination. Biopsy of the most accessible site should be performed early. Open biopsies are considered superior in terms of providing more tissue for special analysis and immunohistochemistry.

The diagnosis of malignant melanoma is established by correlating the cytologic detail with an appropriate immunohistochemistry. ${ }^{[4]}$ The use of an initial screening panel of immunoperoxidase markers (S-100, pancytokeratin, CD45) has become routine in poorly differentiated tumors to determine the cell lineage. This is followed by a second panel of immunoperoxidase markers to narrow the possibilities. At least two melanoma immunoperoxidase markers (S-100, KBA-62, HMB-45, or melanin-A) are needed before a firm diagnosis of malignant melanoma is rendered.

Melanomas may stain for vimentin and are usually positive for S-100 and HMB-45. Clues to diagnosis here include a second mass which is ulcerated on the scalp. Ultimately diagnosis will rest on the two biopsies. Because of history, clinical course, physical findings metastatic malignant melanoma was considered. The resection of the ulcerated mass on the scalp and the tru-cut biopsy from the axillary mass revealed a spindle cell lesion with an immunophenotype strongly supportive of melanoma. The use of tru-cut biopsies on melanocytic tumors poses potential problems including misdiagnosis due to either an unrepresentative sampling or the difficulty in evaluating important diagnostic features.

Although the morphologic and immunohistochemical diversity of malignant melanoma is well known, the diagnosis remains a challenge, particularly when a metastatic tumor is evaluated by fine-needle aspiration cytology. ${ }^{[5]}$ Buehler reported a case of the small cell variant of malignant melanoma mimicking lymphoma in a 78-year-old male who presented with multiple pulmonary masses and a rightsided pleural effusion. ${ }^{[5]}$ Trefzer ${ }^{[6]}$ reported a case of fulminant intravascular disseminating malignant melanoma mimicking acute leukemia. On the other hand, melanoma can originate anywhere in the digestive tract, but the majority of digestive tract lesions are metastatic in nature. 
In patients with end stage melanoma, gastric and small bowel metastases are quite common. In two large autopsy series, gastric metastases were found in about $20 \%$ of the patients studied and small bowel metastases in 35.6\% and 58\% of the patients. ${ }^{[7,8]}$

This case demonstrates the importance of considering melanoma in the differential diagnosis of any patient presenting with an axillary lump and ulcerated scalp lesion with a previous history of unidentified mass excision. The possibility of a metastatic lesion to the axillary area should also be taken into account. Axillary involvement cannot be considered an isolated finding, as it might be the first manifestation of widespread disease. Our casereport illustrates that physicians should consider the possibility of other mass lesions as a way of helping with the diagnosis. Thus, biopsy of such suspicious lesions is advisable. The present case highlights the importance of multidisciplinary teamwork to accurately diagnose these entities and careful history taking, examination, and appropriate biopsy in patients with cancers of unknown primary site.

\section{Declaration of conflicting interests}

The authors declared no conflicts of interest with respect to the authorship and/or publication of this article.

\section{Funding}

The authors received no financial support for the research and/or authorship of this article.

\section{REFERENCES}

1. Lo AA, Peevey J, Lo EC, Guitart J, Rao MS, Yang GY. Isolated Gallbladder Intramucosal Metastatic Melanoma With Features Mimicking Lymphoepithelial Carcinoma. Int J Surg Pathol 2015;23:409-13.

2. Kapnadak SG, Abt D, Risbano MG. Acute respiratory failure mimicking acute respiratory distress syndrome due to parenchymal infiltration by metastatic melanoma. Pulm Circ 2013;3:959-62.

3. Singh S, Desai B, Laskin D. Metastatic melanoma misdiagnosed as a temporomandibular disorder: a case report and review of the literature. J Am Dent Assoc 2014;145:1052-7.

4. Lewis KD, Dollarhide S, Fitzpatrick JE, Gonzalez R, High WA, McCarter MD, et al. Metastatic malignant melanoma from an unknown primary presenting as a large axillary mass. Oncology (Williston Park) 2006;20:763-70.

5. Buehler D, Waknitz M, Rehrauer W, Ranheim E, Selvaggi S. Small cell variant of malignant melanoma masquerading as lymphoma on fine-needle aspiration cytology: a case report. Diagn Cytopathol 2012;40:619-23.

6. Trefzer U, Schlegel C, Sterry W, Späth-Schwalbe E, Possinger K, Denkert C. Fulminant intravascular disseminating malignant melanoma mimicking acute leukemia. Blood 1999;94:1483-4.

7. Patel JK, Didolkar MS, Pickren JW, Moore RH. Metastatic pattern of malignant melanoma. A study of 216 autopsy cases. Am J Surg 1978;135:80710.

8. Oosting SF, Peters FT, Hospers GA, Mulder NH. A patient with metastatic melanoma presenting with gastrointestinal perforation after dacarbazine infusion: a case report. J Med Case Rep 2010;4:10. 